\title{
Yeni Etiketleme Yönetmeliğine Göre Alerjen Gıdalar ve Sağlık Etkileri
}

\author{
Ecem AKAY*, İlkay YILMAZ ${ }^{* * *}$
}

\begin{abstract}
$\ddot{O} \mathbf{z}$
Gıda alerjileri vücudun bir besine karşı spesifik ve tekrarlanabilir bir bağışıklık tepkisi olduğunda ortaya çıkmasıdır. Besin ögelerinin vücuda alınıp kullanılabilmesinin sonucu olarak insanlar; büyür, gelişir ve sağlıklı bir birey olurlar. Kişilerin; yaşı, cinsiyeti, genetik özellikleri, tıbbi geçmişi ve demografik özellikleri beslenmede etkilidir. Günümüzde, özellikle de sağlık alanında hassaslaşan dengeler düşünüldüğünde, yiyecek içecek hizmeti veren işletmeler; gıda alerjisi veya gıda intoleransı olan kişiler için daha dikkatli organize olmak zorundadır. Bu kapsamda Türk Gıda Kodeksi Gıda Etiketleme ve Tüketicileri Bilgilendirme Yönetmeliği ile tüketicilere yönelik düzenlemeler 1 Ocak 2020 tarihi ile hayata geçmiş, bu tarihten itibaren hazır yemek veren restoran, kantin, okul ve hastane gibi toplu tüketim yerlerindeki gıdalar için alerjen bilgilerin tüketiciye sunulmasının zorunluluğu başlamıştır. Bu çalışmada yeni alerjen yönetmeliği ışı̆̆ında alerjen maddelerin sağlık etkiler incelenmiş, menü tasarımı ve menüde bildirimleri hakkında bilgi verilmiştir. Literatür taraması için Science Direct, Pubmed, Ulusal Tez Merkezi ve Google Akademik veri tabanları kullanılmış ve araştırma, Ocak 2020 - Mayıs 2020 tarihleri arasında yapılmıştır. Bu derlemenin amacı yeni etiketleme yönetmeliği ile bildirimi zorunlu olan alerjen gıdaların sağlık etkileri hakkında araştırma yapmak bilimsel literatür çerçevesinde alerjenlerin bildirildiği menü tasarımı konusunda bilgi vermektir.
\end{abstract}

Anahtar Sözcükler: Alerjenler, gıda alerjisi, gıda intoleransı, etiketleme, menü planlama.

\footnotetext{
Derleme Makale (Review Article)

Geliş / Received: 22.05.2020 \& Kabul / Accepted: 29.11.2020

DOI: https://doi.org/10.38079/igusabder.741538

${ }^{*}$ Yüksek Lisans Öğrencisi, İstanbul Ayvansaray Üniversitesi, Lisansüstü Eğitim Enstitüsü, Gastronomi ve Mutfak Sanatları Bölümü, İstanbul, Türkiye, E-posta: akay ecem@outlook.com ORCID https://orcid.org/oooo-0001-8618-7248

** Sorumlu Yazar, Dr. Ö ğr. Üyesi, İstanbul Ayvansaray Üniversitesi, Güzel Sanatlar, Tasarım ve Mimarlık Fakültesi, Gastronomi ve Mutfak Sanatları Bölümü, İstanbul, Türkiye, E-posta: ilkayyilmaz@ayvansaray.edu.tr ORCID https://orcid.org/o0oo-0001-5938-3112
} 


\title{
Allergenic Foods and Their Influence on Health According to New Labelling Regulation
}

\begin{abstract}
Food allergies occur when the body has a specific and reproducible immune response to food. People grow, develop, and become a healthy individual as a result of the nutrients being taken and used in the body. Age, gender, genetic characteristics, medical history, and demographic characteristics of people have an influence on nutrition. Today, considering especially the delicate balance in the healthcare field, businesses providing food and beverage services have to be organized more sensitively for people with food allergies or food intolerances. In this context, the Turkish Food Codex Regulation on Food Labelling and Consumers Information was introduced on January 1st, 2020, and it is obligatory to present the allergen information to consumers in the food consumption places such as restaurants, canteens, schools and hospitals since then. In this study, considering the new allergen regulation, the influence of allergenic substances on health was examined, and information about the menu design and the notifications in the menu was given. Science Direct, PubMed, National Thesis Centre and Google Academic databases were used for literature review, and the research was conducted between January 2020 and May 2020. The aim of this review is to do research on the influence of allergen foods on health that are mandatory to be notified with the new labelling regulation and to give information about the menu design in which allergens are reported within the framework of scientific literature.
\end{abstract}

Keywords: Allergens, food allergens, food intolerance, labelling, menu planning.

\section{Giriş}

Gıda alerjisi vücudun bir besine karşı spesifik ve tekrarlanabilir bir bağışıklık tepkisi olduğunda ortaya çıkmaktadır. Yanıtın hafif, orta veya şiddetli (anafilaksi) olması, yiyecek alerjilerinin genellikle olumsuz bir sonucudur ve dikkatli değerlendirilmelidir. Gıdalara alerjik reaksiyonlar, toplumda anafilaksinin en yaygın nedenidir ${ }^{1}$.Gida kaynaklı alerjik reaksiyonlar deri, gastrointestinal sistem ve solunum yollarını içeren çeşitli semptom ve bozukluklara sebep olur ve İmmünoglobulin E (IgE) aracılı ve IgE aracılı olmayan (hücresel) mekanizmalara atfedilebilir. Herhangi bir gıda alerjik reaksiyona neden olabilse de, gıda kaynaklı alerjik reaksiyonlardan çoğunlukla daha az çeşit gıda sorumludur ve süt, yumurta, yer fistığı, Antep fistığı, balık ve kabuklu deniz ürünleri en çok bilinenleridir². Araştırmacılar, besin alerjisinin önemli bir halk sağlığı sorunu olduğunu belirtmişlerdir. Bununla beraber besin alerjilerinin görülme sıklığının 
belirlenmesi için çeşitli parametreler olduğundan belirlenmesinin zor olduğu ve yapılan araştırmalarda çocuklarda görülen besin alerjisi oranının yüksek olduğunu ve bunun yetişkinlik dönemine kadar uzayabildiğini bildirmişlerdir ${ }^{3}$. Gıda alerjileri genellikle gıda intoleransı ile karıştırılmaktadır. Bir gıda ürünü gastrointestinal sistem boyunca herhangi bir yerde tahrişe neden olduğunda, bu bir intoleranstır ${ }^{1}$. Fakat gıdalara karşı gelişen alerjik reaksiyonlar çeşitli şekilde ortaya çıkmaktadır. Bu reaksiyonların belirtileri sindirim sistemini ve solunum sistemini etkilerken fiziksel olarak vücudu kaplayan deri tabakasında da kendini göstermektedir3.

26 Ocak 2017'de Resmî Gazete'de 29960 saylı Gıda Kodeksi Gıda Etiketleme ve Tüketicileri Bilgilendirme Yönetmeliği yayınlanmıştır. Bu yönetmelikte belirlenen düzenlemeler 1 Ocak 2020 tarihi ile hayata geçmiş, bu tarihten itibaren, hazır yemek veren restoran, kantin, okul ve hastane gibi toplu tüketim yerlerindeki gıdalar için alerjen bilgilerin tüketiciye sunulmasının zorunluluğu başlamıştır. Bu yönetmeliğe göre gıdanın üretiminde veya hazırlanmasında kullanılan ve değişmiş bir formda da olsa son üründe bulunan herhangi bir alerjen bileşen ya da alerjen işlem yardımcısı veya alerjen bir maddeden ya da üründen elde edilen herhangi bir bileşen ya da işlem yardımcısı ile ilgili bilgiler belli kurallara göre menülerde belirtilmelidir. Yönetmelikte belirtilen toplu tüketim yerleri tanımı gıdanın tüketime hazır hale getirildiği ve tüketilmek üzere son tüketiciye sunulduğu; mobil araçlar veya sabit veya hareketli tezgahlar da dâhil olmak üzere hazır yemek hizmeti veren restoranlar, kantinler, okullar ve hastaneler gibi

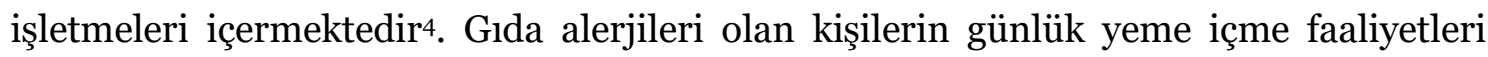
planlama ve öngörü gerektirir. Spontane ve rasgele bir beslenme söz konusu kişiler açısından zordur ve büyük riskler taşımaktadır5. Tüketici seçimini doğru yönde etkilemek bu noktada önemlidir6 ${ }^{6}$ Araştırmalarda, menü tasarımının gıda seçimi üzerinde büyük etkisi olduğu bildirilmiştir7 . Çalışma için Science Direct, Pubmed, Ulusal Tez Merkezi ve Google Akademik veri tabanları kullanılmış ve araştırma, Ocak 2020 Mayıs 2020 tarihleri arasında literatür taraması şeklinde yapılmıştır. Bu derlemenin amacı yeni etiketleme yönetmeliği ile bildirimi zorunlu olan alerjen gıdaların sağlık etkileri hakkında araştırma yapmak bilimsel literatür çerçevesinde alerjenlerin bildirildiği menüler konusunda bilgi vermektir. 


\section{Alerji ve İntolerans}

Alerji; solunan, tüketilen, enjekte edilen, deriye teması eden organik veya inorganik bir maddenin vücudun savunma mekanizmasının var olan çalışmasından daha fazla bir şekilde çalışması ile ortaya çıkan bir durumdur ${ }^{8}$. Günümüz dünyasında, alerjik reaksiyonların sıklığı ve bu reaksiyonlara karşı önlem alınması çok önemlidir. Bu nedenle, araştırılması ve üzerinde durulması gereken bir konu olmuştur. Vücutta alerji semptomlarının başlaması solunum, sindirim, enjeksiyon veya mukozal yüzeylerle doğrudan temas yoluyla gerçekleşir ${ }^{9}$. Gıda alerjisi, herhangi bir gıdanın ağızdan alınması ile alerjik ve immünolojik mekanizmaları tetiklemesi ile mide bağırsak sisteminde, deride, solunum yollarında veya tüm vücutta hafif semptomlardan hayati tehlike yaratabilecek dereceye kadar bulguların ortaya çıktığı bir hastalık grubudur. Tüketilen gıdaların içerisinde yer alan maddeye veya maddelere karşı kişilerin sindirim sisteminin göstermiş olduğu reaksiyon gıda intoleransı olarak tanımlanmaktadır. Gıda intoleransında gıdaya karşı gösterilen reaksiyon bağışıklık sistemiyle ilgili değildir. Gıda intoleransı oluştuğunda; maruz kalan mutsuz olabilir, bazen kişiyi zorlayabilir fakat genellikle kişiye hayati tehlike oluşturmaz ${ }^{10}$. Gıda intoleransı reaksiyonları ile gıda alerjisi reaksiyonları birbirine benzemekle birlikte, intoleransta gıda ya da gıda katkılarının sindiriminden sonra psikolojik ve psikomatik bulgular da oluşabilmektedir. Gıda intoleransının oluşmasında kişinin, genetik geçmişi, alerjik ürün ile ilgili özellikler, ürünün tüketim sıklığı, kişinin bağışıklığı, demografik özellikleri ve stres gibi etkenler rol oynamaktadır.

\section{Dünyada ve Türkiye'de Alerjik Gıdaların Bildirimi}

Türkiye'de alerjik hastalıklar önemli bir sorundur. Çocuklarda alerji görülme oranı yüksektir. Bölgelere göre alerji görülme oranları da değişkenlik göstermektedir. Bir araştırmaya göre, Ege ve Marmara'da daha çok süt alerjisine rastlanırken Akdeniz, Karadeniz, İç Anadolu ve Doğu Anadolu Bölgelerinde yumurta alerjisinin sık görüldüğü tespit edilmiştir. Besin alerjisinin coğrafi özellikler taşımasının başlıca sebebi, beslenme alışkanlıkları, pişirme ve işlemeden kaynaklanan değişkenliklerdir. Yaş grubuna göre ise 0-2 yaş içerisinde en sık süt, 2-5 yaşlarında süt, yumurta, kabuklu deniz ürünleri, kuru yemişler, balık ve undan kaynaklanan besin alerjileri görülmektedir ${ }^{11}$. 
Avrupa genelinde gıda alerjilerinin yaygınlığının hem yetişkinler hem de çocuklar için yaklaşık \% 1 olduğu tahmin edilmektedir. Avrupa ülkelerinde 13 Aralı 2014 tarihinde, tüketicilere gıda bilgilerinin sağlanması ile ilgili 1169/2011 sayılı Avrupa Birliği Yönetmeliği yürürlüğe girmiştir. 13 Aralık 2016 tarihinden itibaren de beslenme bilgileri verme yükümlülüğü geçerli hale gelmiştir. Bu yönetmelikle restoranlar ve kafeler dâhil, önceden paketlenmemiş gıdalar için alerjen bilgilerinin bildirilmesi zorunlu hale gelmiştir ${ }^{12}$. Yönetmelik ülkemizdeki yönetmeliğe benzer maddeler içermektedir.

Amerikalıların gıda alerjenlerinin yarattığı sağlık risklerinden kaçınmasına yardımcı olmak için Kongre, 2004 yılında Gıda Alerjen Etiketleme ve Tüketiciyi Koruma Yasası'nı kabul etmiştir. Yasaya göre alerjen bildirimi hem yerli hem de ithal tüm gıdalar için

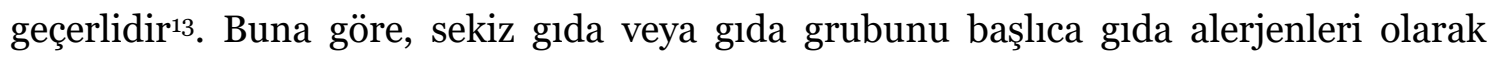
tanımlanmaktadır. Bunlar süt, yumurta, balık (örn. Bas, pisi balı̆̆ı, morina), kabuklu deniz kabukluları (örn. yengeç, ıstakoz, karides), sert kabuklular (örneğin, badem, ceviz), yer fistığı, buğday ve soya fasulyesidir ${ }^{12}$. Gıda ve İlaç Dairesi (FDA), potansiyel gıda alerjen risklerini azaltmak için etiketleme hatalarının nedenlerini araştırma; endüstri ile en iyi uygulamalar üzerinde çalışma ve alerjenlerin varlığını test etmek için yeni yollar geliştirme konularında çalışmalar yapmaktadır. Gıda Güvenliği Modernizasyonu Yasası, özellikle "Risk Bazlı Önleyici Kontroller" (HARPC) ve revize edilmiş "İyi Üretim Uygulamaları" (GMP) ile alerjen kontrollerini gerçekleştirmektediri ${ }^{13}$.

Ülkemizde ise gluten içeren tahıllar, süt ve bunların ürünleri, yumurta, hardal, kereviz, yerfıstığı, acı bakla, balık, soya fasulyesi, sert kabuklu meyveler, deniz kabukluları yumuşakçalar, susam tohumu ile kükürt dioksit ve sülfitler bildirimi zorunlu alerjen gıda olarak yönetmelikte yer almaktadır (Şekil 1). 
Şekil 1: Bildirimi zorunlu alerjen gıdalar

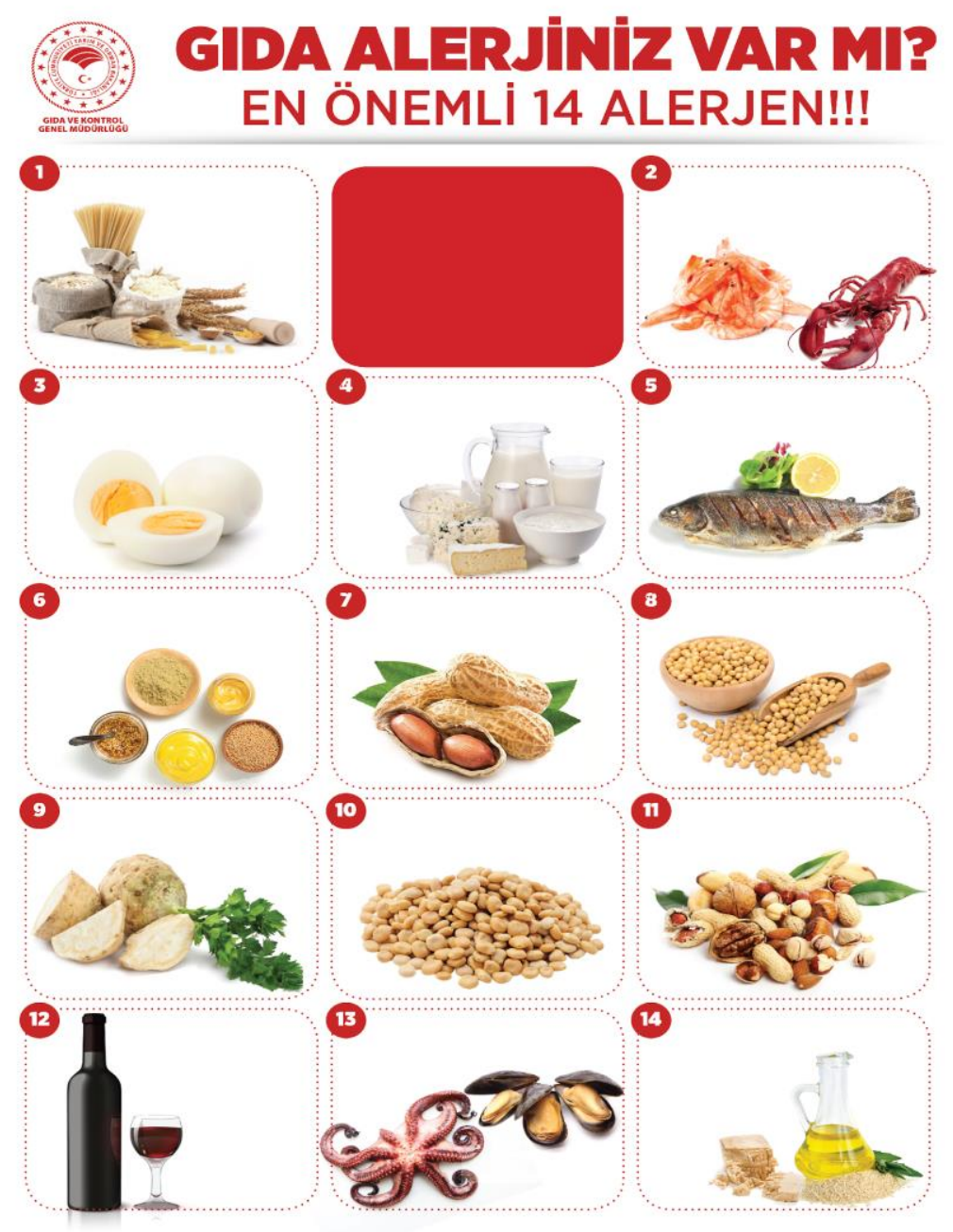

\section{Bildirimi Zorunlu Alerjen Gıdalar ve Sağlı Etkileri}

Alerjenler hafife alınmayacak sağlık sorunlarından biridir. Ayrıca, alerjen uyarılarının yanlış beyanı, eksik bilgisi veya fark edilmemesi nedeniyle ciddi problemler ortaya çıkabilir. Gıda alerjisi için işletmelerde alınabilecek önlemler; risk analizinde alerjen ürünlerin tanımlanması, ürünlere bulaşmalarını engellemek için alerjen prosedürünün oluşturulması, ürünü veya ürünleri etiketleme, ürün reçetesinde varlığını koruyan alerjenlerin reçetede beyan edilmesi, gıda alerjenlerine karşı gıda işletmelerinde çalışan personeller için bilinçlendirme eğitimleri, kişilerin alerjen besinlere karşı hassasiyet durumlarına göre besinleri beslenmelerinden çıkarmaları şeklinde sıralanabilir3. İşletme menülerinde yiyecek seçimlerini daha güvenilir hale getirmek için verimli bir tasarım 
yapılmalıdır. Menülerde bildirimi zorunlu alerjen gıdaların özellikleri ve sağlık etkileri aşağıda belirtilmiştir.

\section{Gluten içeren tahıllar: Buğday (ör. kılçıksız buğday ve kamut-Horasan buğdayı), çavdar, arpa, yulaf veya bunların hibrit türleri ve bunların ürünleri}

Buğday, insana enerji ve besin sağlayan önemli bir tahıl ürünüdür. Gluten, hamur yapma özellikleri için gerekli olan yapısal bir proteindir ve Latince tutkal anlamına gelmektedir. Gluten son zamanlarda önemli bir ilgi ve araştırma konusu olmuştur. Gliadin ve glutenin adı verilen depo proteinlerinin bir bileşimidir. Buğday, arpa, çavdar, yulaf, ilgili türler ve melezlerde ve bunların malt gibi ürünlerinde bulunur. İşlenmiş etler, bira, soya sosu, bazen dondurma ve ketçap gibi ürünler de gluten içerebilir. Çölyak hastalığı bulunan kişiler gluteni tüketmemelidirler ${ }^{14}$. Dünya Sağlık Örgütü tarafından bir gıdanın glütensiz olarak sınıflandırılması için glüten içeriği $20 \mathrm{mg} / \mathrm{kg}^{\prime} ı n$ altında olmalıdır ${ }^{15}$. Çölyak hastalığına sahip immünojenik epitopları barındıran insan popülasyonu dünya nüfusunun \%1-2'si kadardır'16. Çölyak hastalığında diyetin düzenlenmesinin tedavinin ana parçasıdır. Birçok tahıl ve ürünleri doğal olarak glutensiz olmasına rağmen, gluten çapraz kontaminasyon olasılığı göz önünde bulundurulmalıdır ${ }^{17}$.

\section{Kabuklular (Crustacea) ve Bunların Ürünleri}

Yengeç, ıstakoz, karides, midye, istridye, tarak gibi ürünlerin yer aldığı bu alerjen grubunda reaksiyonlar genellikle yetişkinlik çağında ortaya çıkmaktadır ${ }^{18}$. Kabuklulara alerji atopik dermatit, astım, ürtiker şeklinde olabileceği gibi ileri durumlarda anafilaktik şok etkisi yapabilmektedir. Deniz kabuklularına alerji; cilt testi veya kan testi ile belirlenebilmektedir ${ }^{19}$. Deniz kabukluları, en yaygın besin alerjilerinden biridir. Bu alerji genellikle çoğunlukla yetişkinlikte (\%60) ortaya çıkar yaşam boyu sürmektedir. Kabuklu deniz hayvanları kabuklular ve yumuşakçalar olarak iki gruba ayrılırlar. Deniz kabuklularına ciddi alerjisi olanlar dokunmaktan ve balık pazarlarına gitmekten de kaçınmalıdırlar. Yiyecekle çapraz temas riskinin yüksek olduğu restoranlarda da hayvanın proteini buharda olabileceğinden risk teşkil edebilmektedir. Bu gruptaki ürünler iyot içerdiğinden iyot alerjisi ile karıştırılabilir²o. 


\section{Yumurta ve Yumurta Ürünleri}

Dünyada en yaygın gıda alerjenleri sırasıyla süt $(\% 32,2)$ ve yumurtadır (\%30). Özellikle bebeklik ve erken çocukluk döneminde bu alerji çok yaygındır. Çocukluk çağı besin alerjisinde yumurta ve inek sütü, dünyanın hemen her yerinde ilk iki sırayı paylaşmaktadır. Bunun temel nedeni bu iki besinin tüm kültürlerin ortak ve yaygın kullanılan gıdaları olmasıdır ${ }^{21}$. Ovalbumin ve ovomokoid, ovotransferrin ve konalbumin yumurta beyazının içerdiği önemli alerjenlerdir. Yıllar geçtikçe alerjen etkisini yitirmektedir. Yumurta alerjisinde egzama veya kaşıntı, deride ve gözde çeşitli alerjik lezyonların görülme sıklığı diğer besin alerjenlerine kıyasla fazladır. Yumurta alerjisi, yumurtanın kendisinin veya yumurta içeren ürünlerin tüketiminden sonra, kısa bir süre içerisinde kızarıklık, hırıltılı solunum, kusma ve ishal ile kendini belli edebilir. Yumurta ve yumurtalı besinlere karşı alerjik reaksiyon gösteren kişiler bu besin grubunun dâhil olduğu gıdaları tüketmemeli, beslenmelerinden çıkarmalıdır ${ }^{8}$. Yumurta ve yumurta ürünleri, albümin ve globülin içeren maddeler, yumurta ile hazırlanan mayonez ve yumurta içeren makarna gibi gıdalar risk grubudur ${ }^{21}$. Yumurta alerjisi küçük çocuklarda (<5 yaş) daha yaygındır ve yaşam kalitesi üzerinde önemli olumsuz etkileri vardır ve yumurta alerjisi bildirilen çocukların yaklaşık üçte ikisinin pişmiş yumurtaya alerjisi bildirilmiştir ${ }^{22}$.

\section{Balık ve Balık Ürünleri}

Bu gruba dâhil olan birçok besin türü vardır. Çocuklarda bu besin grubunun alerjen tepkimesi, sıklıkla astım veya egzama belirtisi olmakla birlikte kaşıntı, deri ve gözde görülen ürtikerdir. Aşırı hassas kişilerde balık ve deniz ürünleri ağıza alındığında etki gösterebilir. Ayrıca bu kişilere balık kokusu bile alerji yapabilir ${ }^{8}$. Balıklardan elde edilen balık yağları kullanımında da çapraz bulaşma nedeniyle protein olabileceği için alerji görülebilir. Balıklar ve kabuklu deniz hayvanları aynı aileden değildirler bu sebeple birine alerjisi olanın diğerine de alerjisi olabilir diye düşünülmemelidir²2. Balık tüketimleri sonucunda oluşan deride kızarma ve çeşitli lezyonlar şeklinde alerjik reaksiyonlar görülebilir aynı zamanda kaşıntı oluşabilir. Astım ve alerjik nezle oluşabileceği gibi karın ağrısı, bulantı, ishal, kramplar ve kusma veya ileri düzeyde anaflaktik şok oluşabilir8. 


\section{Yerfistığı ve Yerfistığı Ürünleri}

Bu ürünler potansiyel olarak anafilaksiye sebep olabilen önemli alerjenlerden olup en sik görülen alerji türüdür ve ölümle sonuçlanabileceğinden çok tehlikelidir. Bu alerjiye sahip kişiler çok dikkatli besin tüketmelidirler. Alerjinin oluşmaması için fıstık ve fıstık ürünleri ile kabuklu yemişlerden uzak durulması ve menü içeriklerinin detaylı bir şekilde incelenmesi gerekmektedir²3. Yer fıstığı alerjisi çocukluk döneminde başlayıp ömür boyu sürebilen bir alerji çeşididir. Çok duyarlı kişilerde çok küçük miktarları bile reaksiyona sebep olabilir, hatta solunum yolu ile bile ortamda bulunan alerjenden ürtiker ve hışırtılı solunum şeklinde etkilendikleri görülmüştür ${ }^{24}$.

\section{Soya Fasulyesi ve Soya Fasulyesi Ürünleri}

Soya fasulyesi baklagiller grubundadır ve alerjisi özellikle çocuklarda görülmektedir. Çoğu çocukta on yaşına kadar zamanla azalmakta ve genellikle bebeklik çă̆ında alerjik reaksiyonlara sebep olmaktadır. İnek sütü alerjisi ile yandaş gidebilmekte, inek sütü alerjisi olan bebeklerde mamalarda yer alan soyalara da reaksiyon gösterebilmektedir. Hafif alerji belirtileri olabilirken, şiddetli anafilaksik şoklar da görülebilmektedir. Alerjinin oluşmaması için soya ve ürünleri tüketilmemelidir ${ }^{25}$. Soya, ürünlerde direkt kullanıldığı gibi; ucuz, yüksek kalitede protein içermesi nedeniyle lesitin, emülsiye edici yan ürün, stabilize edici ürün şeklinde katkı maddesi olarak da kullanılabilmektedir. Gizli kullanımı menülerde bildirilmelidir ${ }^{26}$. Baklagiller arasında çapraz temas söz konusu olabileceği de düşünülmelidir fakat bireylerin birden fazla baklagillere karşı alerjisi olması nadir görülen bir durumdur ${ }^{27}$.

\section{Süt ve Süt Ürünleri}

Kişilerin anne sütünden sonra beslenme ürün listesinde ilk suralarda bulunan inek sütüne karşı oluşan alerji her yüz çocuktan üçünde belirtilerini göstermektedir ${ }^{8}$. Bu gıdanın çocukların beslenmesinde birincil besin olduğu düşünülürse bu durum normaldir. Süt alerjisi ortalama 3.ayda başlayıp ilerleyen zamanda duyarlılı̆̆ın azalması ile 2-3 yaşlarında yok olmaktadır. Alerji semptomları ishal, kusma, dışkıda kan, huzursuzluk ve ağlama ile kendini gösterebilir. Bu tarz bireylere daha az alerjik olması sebebiyle proteinin parçalanmış hali yani hidrolizatları verilebilir²8. İnek sütü proteinleri kazein ve peynir altı suyu proteinleri olmak üzere başlıca 2 grupta toplanır ${ }^{27}$. Kazein bu proteinlerin \%76-86'sını oluşturmaktadır ve yirmiden fazla protein çeşidi vardır fakat 
özellikle beşi alerjik özellik göstermektedir. Bu proteinler; alfa laktoglobulin, kazein, gamma globülin, albümin ve beta laktoglobulindir. Bu bileşenlere alerjisi olan çocuklar ve yetişkinler çapraz bulaşma riskinin doğuracağı tehlikeden ötürü hayvansal süt grubunda olan koyun ve keçi sütü gibi diğer süt ve ürünlerine de alerjik reaksiyon gösterebilmektedir ${ }^{8}$. Bu kişiler çapraz duyarlılık sebebiyle koyun ve keçi sütlerini de tüketmemeleri gerekebilir²9. Alerji sebebiyle beslenmeden çıkartılması gereken süt ve süt ürünleri tereyağı, tereyağı aromalı diğer yağlar, margarin, kazein, kazeinatlar, sütten elde edilen peynir çeşitleri, yoğurt, sütten elde edilen krema, muhallebiler, yarı hidrolize edilmiş ürünler, laktobulmin, laktoglobulin, laktoz, laktuloz içeren ürün veya ürünler, süt (az yağlı, yarım yağlı, süt tozu, süt proteinleri, diğer hayvan sütleri), pudingler, helva gibi süt içeren gıdalar ve gıdaya aroma katıcı diğer maddelerdir ${ }^{8}$.

\section{Sert Kabuklular}

Bu grupta; badem, findık, ceviz, kaju, Antep fistığı gibi ürünler bulunmaktadır ayrıca bunları içeren ürünlere de (krakerler, çerezler, şekerlemeler, dondurmalar, çeşitli soslar, çikolatalar aromalı alkol, kahveler vb.) dikkat edilmesi gereklidir. Çünkü bu gıdalardan tüketilen düşük miktarlar bile alerjiye sebep olabilmektedirº ${ }^{\circ}$. Küçük miktarlar bile alerji için etkin olduğundan çapraz temasla bulaşma riskleri yüksektir. Bu alerji çeşidi yaşam boyu devam edebilmektedir fakat büyüdükçe alerjiyi atlatan çocukların oranı da yüksektir31. Fındık alerjisi eser miktarlarda bile sistemik reaksiyonlara neden olabilmektedir. Fındık alerjisi semptomları hafif ve potansiyel olarak tehlikeli anafilaksi arasında değişebilir32 ${ }^{2}$. Fındık büyük ölçüde pastacılık ürünlerinde özellikle pasta ve dondurma üretiminde kullanılır. Gıda endüstrisinde geniş fındık kullanımı, fındık alerjisi olan kişiler için önemli bir risk oluşturmaktadır. Fındık, bazı gıda ürünlerinde eser miktarda olduğu için belirtilmeyebilir veya bu gıdalardan kaçınma çabalarına rağmen kazayla yutulması halinde alerjik reaksiyonlara sebebiyet verebilir33. Bir çalışma yumurta ve inek sütü alerjisinden sonra en çok rastlanan alerji \%21,9 ile findık alerjisi olarak bulunmuştur. Diğerleri \%11,7 ile yer fistığı ve \%7 ile ceviz şeklindedir34.

\section{Kereviz ve Kereviz Ürünleri}

Kereviz alerjisi olarak ciltte kaşıntı, ürtiker, ağız çevresi kabarması şeklinde kendini gösterebilir. Aynı zamanda bulantı, astım ve ileri safhalarda anaflaktik şok görülebilmektedir. Eğer kereviz sebze soslarında, baharat olarak vb. şekilde gıdalarda 
gizli şekilde kullanılmışsa bunu menüde bildirmek besin alerjisi olan kişiyi etkilemesine engel olacaktır ${ }^{30}$.

\section{Hardal ve Hardal Ürünleri}

Hardal alerjisi iyi bilinmeyen bir alerji çeşididir. Hardal kaynaklı alerjinin ilk raporlarından biri, 1980'de Panconesi tarafından hardallı pizza yiyen bir hastada ciddi bir anafilaktik reaksiyon gerçekleşmesi ile tanımlanmıştır. Hardal tohumu alerjisi son on yılda, özellikle Güney Avrupa'daki bazı araştırmacılar tarafından büyük ilgi görmüş ve araştırılmaya başlanmıştır35. Hardal alerjisi olan hastalar alerjiyi hafif semptomlarla geçirebilir ancak daha şiddetli semptomlar ve sistemik reaksiyonların gibi daha sık meydana geldiği bildirilmektedir. Hardaldaki alerjik bileşen, proteaz fraksiyonu, özellikle tohum depo proteinlerine, diğer alerjik tohumlara, kabuklu yemişlere ve baklagillere benzerdir. Hardalın öğütülmüş bütün tohumları ve bunların fraksiyonları çorbaların, sosların ve diğer hazır gıdaların tadını iyileştirmek için kullanılabilir. Gıdaya tatlandırıcı olarak büyük ölçüde rafine hardal yă̆ı eklenebilir36. Menülerde gizli kullanımına dikkat edilerek bildirimi yapılmalıdır.

\section{Susam Tohumu ve Susam Tohumu Ürünleri}

Ülkemizde alerjen bildirimi zorunlu alerjen listesine eklenen susam alerjisi özellikle Uzak Doğu ülkelerinde ve Amerika'da yaygın görülmektedir. Susama hassasiyeti olan kişilerde anafilaktik şok tetiklenebilmektedir37. Susam fırın ürünlerinde sıkça kullanılmaktadır ve susama alerjisi olan kişi sayıları gün geçtikçe artmaktadır ${ }^{8}$. Amerika Birleşik Devletleri'ndeki 1,5 milyondan fazla çocuk ve yetişkin susam alerjisinin etkisi altındadır. Northwestern Üniversitesi araştırmacıları, susam alerjisinin ciddi reaksiyonlara neden olabilmesine rağmen, susamın genellikle gıda ürünlerinde beyan edilmediğini bildirmektedir. Chicago'daki Northwestern Feinberg Tıp Okulu'nda Gıda Alerjisi ve Astım Araştırmaları Merkezi'nin direktörüne göre susam çok fazla gıda içerisinde yer alabilmekte ve bu yüzden alerjileri önlemek için bildirimi zorunlu olmalıdır39. 


\section{Kükürt dioksit ve sülfitler (tüketime hazır veya üreticilerin talimatlarına göre hazırlanan ürünler için, toplam SO2 cinsinden hesaplanan konsantrasyonu $10 \mathrm{mg} / \mathrm{kg}$ veya $10 \mathrm{mg} / \mathrm{L}$ 'den daha fazla olanlar)}

Sülfür, sülfür dioksit, sodyum sülfit, sodyum bisülfit, potasyum bisülfit, sodyum metabisülfit ve potasyum metabisülfit gıda koruyucuları gıdalarda işlenmiş meyve, sebze ve kabuklu deniz hayvanlarının esmerleştirilmesi işlemlerinde kullanılmaktadır. Sülfitler doğrudan et veya kümes hayvanları ürünlerinde kullanılmaz fakat et veya kümes hayvanları ürünleri sülfit içerebilir. Sülfitlere karşı toleransı olmayan kişiler, gögüs sıkışması, kurdeşen, mide krampları, ishal ve solunum problemleri yaşayabilmektedirler. Sülfit intoleransı için altta yatan mekanizmalar tam olarak anlaşılamamıştır. Bazı astımı olan kişilerde sülfitlere duyarlı olma riski yüksek gibi görünmektedir. Sülfitlere maruz kaldıktan sonra astım semptomları artmaktadır. Sülfür ajanlarının varlığı, eğer et veya tavuk ürünündeki konsantrasyon $10 \mathrm{mg} / \mathrm{kg}$ veya $10 \mathrm{mg} / \mathrm{L}$ veya daha yüksekse bu ürünleri menüde bildirmek gerekmektedir. Bununla birlikte, birden fazla ayrı bileşen, $10 \mathrm{mg} / \mathrm{kg}$ veya $10 \mathrm{mg} / \mathrm{L}$ veya daha fazla sülfit içeriyorsa toplam ürün olmasına rağmen ayrı bir ürün gibi beyan edilmelidir ${ }^{40}$.

\section{Acı Bakla ve Acı Bakla Ürünleri}

Beslenmede bitkisel bir protein (proteinleri albümin, globülin, prolamin ve glutelin) kaynağı olarak tüketilen acı bakla aynı zamanda yüksek diyet lifi kaynağıdır. Fenolik madde, fitosteroller, tokoferoller ve skualenler gibi fitokimyasallar da içermektedir. Acı bakla ayrıca üstün su bağlama ve emülsiyon oluşturma gibi fonksiyonel özellikler gösterir. Acı bakla içerdiği tripsin inhibitörleri ve insanlar için toksik olan kinolizidin alkaloidleri sebebiyle alerjen özellik gösterebilmektedir ${ }^{41}$.

\section{Yumuşakçalar ve Ürünleri}

Yumuşakçalarda tropomyosin, myosin ağır zinciri, hemosyanin gibi alerjen maddeler bulunmuştur. Midye, istiridye, kalamar ve denizkulağında gıda alerjenleri görülmektedir. Yumuşakçalar deniz kirliliğine maruz kaldığında alerjen özellikler de geliştirebilirler ${ }^{42}$. Yiyecek ve içecek işletmelerinde alerjen yönetiminde işletmeler, gerekli aksiyonları aldıktan ve yeterli bilgiyi personellerine beyan ettikten sonra, menü tasarımı ile bu süreci sonlandırmalıdır. İşletmelerde bildirilen alerjenlerle ilgili tüketici algısının tespit edilmesi ile işletmelerin değişiklikleri yapabilmesi açısından yardımcı anketler gibi 
yöntemlerle takipler yapılmalıdır. Mutfak personelinin kullandığı araç gereçten alerjenin bulaşması, kızartma yağları ve ızgaralardan bulaşma gibi riskler konusunda personelin eğitilmesi gerekmektedir. Yiyecek ve içecek hizmeti veren işletmelerin kartvizitlerinin menüleri olduğu düşünülürse, işletmeler konuyla ilgili nihai değerlendirmeyi menüler üzerinden yapmaktadır. İşletmeler, alerjen yönetimi ile müşterilerin tüketim tercihlerini kolaylaştırmayı amaçlamalıdırlar.

\section{Sonuç ve Öneriler}

Son yıllarda alerji oluşturan gıdalar ve alerjik bireyler giderek artmaktadır. Toplumlar arası besin alerjilerindeki farklılıklara bakıldığında alerjilerin hangi besinden ileri geldiği açısından büyük farklar vardır. Çünkü toplumların beslenme alışkanlıkları farklıdır ve bir toplum hangi besinleri daha fazla tüketiyorsa o besinlere karşı daha fazla alerji görülmektedir. Sonuç olarak tüketim alışkanlıklarımızdaki değişime paralel olarak yemeklerimizin önemli bir bölümünü dışarıda tüketmeye başladığımız için ev dışında besin tüketimi besin alerjisi olan hastalar için risk oluşturmaktadır. Son aylarda dünya gündemine yerleşen COVID-19 pandemisi gıda konusuna daha da önem verilmesi gereğini açı̆̆a çıkarmıştır, son bilgilere göre gıdanın virüsün muhtemel bir kaynağı veya bulaşma yolu olduğuna dair bir kanıt yoktur. Hem küreselleşmenin etkisi hem de ülkemizin her geçen yıl dışa daha fazla açılması ile tüketim alışkanlıklarımız değişmektedir. Tüm bunlar göz önüne alındığında alerjen yiyeceklerin içeriklerinin menülerde açık şekilde yazılması, ayrıca yiyecek hazırlayan mutfak personelinin alerjenler konusunda bilinç düzeyinin artması ve alerjen listelerinin güncel veriler ışı̆̆ında sürekli yenilenmesi gerekmektedir.

\section{KAYNAKLAR}

1. Grief SN. Food allergies. Prim Care - Clin Off Pract. 2016;43(3):375-391.

2. Sicherer SH, Sampson HA. Food allergy. J Allergy Clin Immunol. 2010;2:116125.

3. Tayfur M, Ünlüoğlu İ. Besin allerjisi. Gıda. 1996;21(4):293-296. 
4. Başbakanlık Mevzuatı Geliştirme ve Yayın Genel Müdürlüğü. Türk Gıda Kodeksi Gıda Etiketleme ve Tüketicileri Bilgilendirme Yönetmeliği. https://www.resmigazete.gov.tr/eskiler/2017/01/20170126M1-6.html. Erişim Tarihi 11 Mayıs 2020.

5. Borchgrevink CP, Elsworth JD, Taylor SE, Christensen KL. Food intolerances, food allergies and restaurants. J Culin Sci Technol. 2009;7(4):259-284.

6. Kang J, Jun J, Arendt SW. Understanding customers' healthy food choices at casual dining restaurants: using the value-attitude-behavior model. Int J Hosp Manag. 2015;48:12-21.

7. Ozdemir B, Caliskan O. A review of literature on restaurant menus: specifying the managerial issues. Int J Gastron Food Sci. 2014;2:3-13.

8. Öztürk M, Besler T. Besin Alerjileri. T.C. Sağlık Başkanlı̆̆ı Temel Sağlık Hizmetleri Genel Müdürlüğü Beslenme ve Fiziksel Aktiviteler Daire Başkanlığı. Ankara: Sağlık Bakanlığı Yayını; 2008.

9. Kırsaçlığlu CT, Özden A. Besin alerjileri. Güncel Gastroenteroloji. 2007;10:148-159.

10. Akoğlu A, Oruç M. Metabolik gıda intoleransları. Harran Tartm ve Gıda Bilimleri Dergisi. 2018;22(2):284-295.

11. Paykoç E. Gıda Alerjisi, Gıda Alerjisinin Mekanizması, Tanı Yöntemleri ve Alerjinitesinin Azaltılmasında Kullanılan Teknikler [Lisans Tezi]. Trabzon, Türkiye: Gıda Mühendisliği Bölümü, Avrasya Üniversitesi Mühendislik ve Mimarlık Fakültesi; 2017.

12. Nutrition Labelling. www.fsai.ie ; https://ec.europa.eu/food/safety/labelling nutrition/labelling legislation/nut rition-labelling en. Erişim Tarihi 14 Mayıs 2020.

13. Food Allergens. FDA. https://www.fda.gov/food/food-ingredientspackaging/food-allergens. Yayınlanma tarihi o8 Şubat 2018. Erişim Tarihi: 14 Mayıs 2020.

14. Akyüz HC. Besin Alerjisi Olan Çocukların Beslenme Durumunun Değerlendirilmesi [Uzmanlık Tezi]. Ankara, Türkiye: Çocuk Sağlığı ve Hastalıkları Anabilim Dalı, Hacettepe Üniversitesi Tıp Fakültesi; 2018. 
15. Pasquali D, Blundell M, Howitt CA, Colgrave ML. Catcher of the rye: detection of rye, a gluten-containing grain, by LC-MS/MS. J Proteome Res. 2019;18(9):3394-3403.

16. Jouanin A, Schaart JG, Boyd LA. Outlook for coeliac disease patients: towards bread wheat with hypoimmunogenic gluten by gene editing of $\alpha$ - and $\gamma$-gliadin gene families. BMC Plant Biol. 2019;19(1):333. doi:10.1186/s12870-019-1889-5.

17. Raju N, Joshi AKR, Vahini R, Deepika T, Bhaskarachari K, Devindra S. Gluten contamination in labelled and naturally gluten-free grain products in southern India. Food Addit Contam - Part A Chem Anal Control Expo Risk Assess. 2020;37(4):531-538.

18. Sievers S, Rawel HM, Ringel KP, Niggemann B, Beyer K. Wheat protein recognition pattern in tolerant and allergic children. Pediatr Allergy Immunol. 2016;27(2):147-155.

19. Karakiliç M, Suna S, Tamer CE, Çopur ÖU. Gıda alerjisi reaksiyonları. Uluda $\breve{g}$ Üniversitesi Ziraat Fakültesi Dergisi. 2014;82:73-82.

20. Tekiner İ, Ay M, Mutlu H. Bir gıda güvenliği ve sağlık sorunu: balık ve balık ürünleri kaynaklı alerjenler. Aydın Gastronomy. 2020;4(1):1-9.

21. Can C. Clinical and laboratory characteristics of patients with food allergy: single center experience. Sisli Etfal Hastan Tip Bulletin. 2019;53(3):296-299.

22. Samady W, Warren C, Wang J, Das R, Gupta R. Egg allergy in US children. $J$ Allergy Clin Immunol Pract. 2020;S2213-2198(20):30418-9.

23. Food Allergy Research \& Education. https://www.foodallergy.org/ Erişim Tarihi 11 Mayıs 2020.

24. Frequently Asked Questions about Food Allergies | FDA. https://www.fda.gov/food/food-allergens/frequently-asked-questions-aboutfood-allergies. Erişim tarihi 14 Mayıs 2020.

25. Savage JH, Kaeding AJ, Matsui EC, Wood RA. The natural history of soy allergy. $J$ Allergy Clin Immunol. 2010;125(3):683-686.

26. Yu W, Freeland DMH, Nadeau KC. Food allergy: immune mechanisms, diagnosis and immunotherapy. Nat Rev Immunol. 2016;16(12):751-765.

27. Ortolani C, Ispano M, Scibilia J, Pastorello EA. Introducing chemists to food allergy. European Journal of Allergy and Clinical Immunology. 2001;56:5-8. 
28. Buttriss J. British Nutrition Foundation. Adverse Reactions to Food: The Report of a British Nutrition Foundation Task Force. John Wiley \& Sons; 2001.

29. Tokuç R. Gıda İntoleransının 30-45 Yaş Arası Sedanter Bireyler Üzerindeki Fiziksel ve Ruhsal Etkileri [Yüksek Lisans Tezi]. İstanbul, Türkiye; Antrenörlük Eğitimi Anabilim Dalı Hareket ve Antreman Bilim Dalı, İstanbul Gelişim Üniversitesi Sağlık Bilimleri Enstitüsü; 2017.

30. Gül F, Dikmen D. Kadın tüketicilerde besin etiketi okuma alışkanlıkları ve alerjen bilgi düzeyinin saptanması. $J$ Nutr Diet. 2018;46(2):157-165.

31. Villalta D, Scala E, Mistrello G, Amato S, Asero R. Evidence of cross-reactivity between different seed storage proteins from hazelnut (corylus avellana) and walnut (juglans regia) using recombinant allergen proteins. Int Arch Allergy Immunol. 2019;178(1):89-92.

32. Flinterman AE, Akkerdaas JH, Knlsta AC, Van Ree R, Pasmans SG. Hazelnut allergy: From pollen-associated mild allergy to severe anaphylactic reactions. Curr Opin Allergy Clin Immunol. 2008;8(3):261-265.

33. Enrique E, Pineda F, Malek T. Sublingual immunotherapy for hazelnut food allergy: A randomized, double-blind, placebo-controlled study with a standardized hazelnut extract. J Allergy Clin Immunol. 2005;116(5):1073-9.

34. Köken G. Çocukluk Çağı Besin Alerjilerinin Klinik Fenotiplendirmesi [Uzmanlık Tezi]. Ankara, Türkiye; Çocuk Sağlı̆̆ı ve Hastalıkları Ana Bilim Dalı, Hacettepe Üniversitesi; Tıp Fakültesi; 2019.

35. Rancé F, Dutau G, Abbal M M. Mustard allergy in children. Allergy. 2000;55(5):496-500.

36. Koppelman SJ, Vlooswijk R, Bottger G, et al. Development of an enzyme-linked immunosorbent assay method to detect mustard protein in mustard seed oil. Journal offood protection, 2007;70(1):179-83.

37. Günaydın CN, Demir E. O https://docplayer.biz.tr/111018089-Olgu-sunumuuzm-dr-nursen-cigerci-gunaydin-tekirdag-devlet-hastanesi-prof-dr-esendemir-eutf-cocuk-alerji-ve-immunoloji-bd.html Erişim Tarihi 11 Mayı 2020.

38. Minnicozzi M, Sawyer RT, Fenton MJ. Innate immunity in allergic disease. Immunol Rev. 2011;242(1):106-127.

39. Freedman SS, Sellars W. Food sensitivity. A study of 150 "allergic" children. $J$ Allergy. 1959;30(1):42-49. 
40. Ongoing Verification of Product Formulation and Labeling Targeting the Eight Most Common ("Big 8") Food Allergens. United States Department Of Agriculture Food Safety and Inspection Service. www.fsis.usda.gov. Erişim Tarihi 16 Mayıs 2020.

41. Çetiner M, Bilek Ersus S. Bitkisel protein kaynakları. Çukurova Tarım Gıda Bil Der. 2018;33(2):111-126.

42. Kocatepe D, Turan H. Su ürünleri alerjisi sea food allergy. Mehmet Akif Ersoy Üniversitesi Fen Bilim Enstitüsü Derg. 2012;3(2):46-51. 